\title{
nane \\ Application of Multiplex TaqMan Real-Time PCR Assay in Survey of Five Lily Viruses Infecting Lilium spp.
}

\author{
Leifeng $\mathrm{Xu}^{+}{ }^{+}$, Meng Song ${ }^{\dagger}$ and Jun Ming ${ }^{*}$ \\ Institute of Vegetables and Flowers, Chinese Academy of Agricultural Sciences, Beijing 100081, China; \\ xuleifeng@caas.cn (L.X.); 15558111707@126.com (M.S.) \\ * Correspondence: mingjun@caas.cn; Tel.: +86-10-8210-5945 \\ † These authors contributed equally to this work.
}

Citation: Xu, L.; Song, M.; Ming, J. Application of Multiplex TaqMan Real-Time PCR Assay in Survey of Five Lily Viruses Infecting Lilium spp. Agronomy 2022, 12, 47. https:// doi.org/10.3390/agronomy12010047 Academic Editor: Salvatore Davino

Received: 24 October 2021

Accepted: 24 December 2021

Published: 26 December 2021

Publisher's Note: MDPI stays neutral with regard to jurisdictional claims in published maps and institutional affiliations.

Copyright: (C) 2021 by the authors. Licensee MDPI, Basel, Switzerland. This article is an open access article distributed under the terms and conditions of the Creative Commons Attribution (CC BY) license (https:// creativecommons.org/licenses/by/ $4.0 /)$.

\begin{abstract}
Lily symptomless virus (LSV), Lily mottle virus (LMoV), Cucumber mosaic virus (CMV), Shallot yellow stripe virus (SYSV), and Plantago asiatica mosaic virus (PlAMV) are five of the economically important viruses infecting lilies (Lilium spp.) worldwide. In order to prevent the occurrence and spread of these viruses, it is necessary to develop a rapid, effective, and sensitive detection method for the simultaneous detection and specific quantification of these viruses. In this study, specific primers and probes for multiplex TaqMan real-time PCR assays designed from conserved regions of the coat protein sequence of each virus were used for the simultaneous detection of these viruses in lilies (Lilium spp.). The optimal concentration of primers and probes and reaction annealing temperature were $20 \mu \mathrm{M}$ and $55.9^{\circ} \mathrm{C}$, respectively. The detection limits of the assay were $1.33 \times 10^{2}$, $1.27 \times 10^{1}, 1.28 \times 10^{1}, 2.33 \times 10^{2}$, and $2.01 \times 10^{2}$ copies $\cdot \mu \mathrm{L}^{-1}$ for LSV, LMoV, CMV, SYSV, and PlAMV, respectively. Specificity was determined using seven viral pathogens of lilies. Variability tests of intra- and inter-assays showed high reproducibility with coefficients of variation $<2 \%$. The multiplex TaqMan real-time PCR assay was used to detect these viruses from lily samples in China. In brief, our developed assay showed high specificity, sensitivity, and reproducibility for the simultaneous detection and differentiation of five lily-infecting viruses and can be used for certification and quarantine programs.
\end{abstract}

Keywords: Lilium spp.; LSV; LMoV; CMV; SYSV; PlAMV; multiplex TaqMan real-time PCR; simultaneous detection

\section{Introduction}

Lilies (Lilium spp.) are among the most important ornamental plants worldwide and are also widely grown for their nutritional and medicinal value in Eastern Asia [1-3]. Lily cultivars are usually propagated vegetatively, resulting in virus transmission from generation to generation. Among viruses infecting lilies, Lily symptomless virus (LSV; genus Carlavirus, family Flexiviridae), Cucumber mosaic virus (CMV; genus Cucumovirus, family Bromoviridae), Lily mottle virus (LMoV; genus Potyvirus, family Potyviridae), Shallot yellow stripe virus (SYSV; genus Potyvirus, family Potyviridae), and Plantago asiatica mosaic virus (PlAMV; genus Potexvirus, family Alphaflexiviridae) are five economically important viruses [4-9]. LSV-infected plants show mild, pale vein clearing and mottle on leaves, which generally turn yellow fairly quickly [6,7]. LMoV can cause flower-color breaking, leaf mottle, leaf mosaic, chlorotic and yellow streaking, vein clearing, leaf curling, and narrowing [6,7]. CMV-infected lily leaves show chlorotic or yellow spotting, inter-veinal striping or vein-clearing and sometimes malformations [6,7]. Leaves infected with SYSV show yellow stripe symptoms [8]. When infected with PlAMV, leaves of infected plants are often brittle, flower production is declined, and the plants gradually die [9]. Mixed viral infections in lily plants can cause much more severe symptoms, including dwarfism [7]. In order to prevent the occurrence and spread of these viruses, it is essential to establish a rapid, effective, and sensitive detection method for the simultaneous detection and specific quantification of these viruses. 
Many diagnostic approaches have been developed to detect viruses, such as serological methods relying on specific antibodies (enzyme-linked immunosorbent assay (ELISA), double-antibody sandwich-ELISA (DAS-ELISA), immunochromatographic strip test, etc.) and molecular biology methods relying on specific primers/probes (reverse transcriptionpolymerase chain reaction (RT-PCR), real-time PCR, loop-mediated isothermal amplification (LAMP), etc.) [10-17]. ELISA, uniplex RT-PCR, and LAMP have been used to detect lily viruses [18-22]; however, these techniques can only be used to detect one virus per reaction and are time-consuming, laborious, and expensive when several viruses have to be detected in numerous samples [23]. These limitations can be overcome by using multiplex TaqMan real-time PCR assay, which enables the simultaneous detection and identification of several viruses in a single reaction [14]. Multiplex TaqMan real-time PCR has been applied widely for pathogen detection in humans [14,24-27] and animals [10,28-35]. Recently, this method has also been used to detect viruses in sweet potatoes, pome fruit trees, stone fruit trees, and fig trees [36-40]. However, this method has not been used for the simultaneous detection of LSV, LMoV, CMV, SYSV, and PIAMV in lily plants.

In this study, a set of specific primers and probes were designed for the detection of five economically important viruses (LSV, LMoV, CMV, SYSV, and PlAMV) infecting lily plants. Then, an efficient multiplex TaqMan real-time PCR was developed for the simultaneous detection and differentiation of these lily viruses.

\section{Materials and Methods}

\subsection{Materials}

Fresh leaves from lily samples grown in greenhouses at the Chinese Academy of Agricultural Sciences (Beijing, China), which were confirmed to be infected with LSV, LMoV, CMV, SYSV, and PlAMV by RT-PCR and sequencing, were used to establish and optimize the multiplex TaqMan real-time PCR assay.

\subsection{RNA Extraction and Reverse Transcription}

Total RNA was extracted from lily leaves using an RNAprep pure Plant Kit (Tiangen, Beijing, China), according to the manufacturer's protocol. First-strand cDNA was synthesized using a SuperScript III reverse transcription kit (Invitrogen, Carlsbad, CA, USA), following the manufacturer's instructions. Briefly, $5 \mu \mathrm{g}$ total RNA was combined with $1 \mu \mathrm{L}$ oligo $(\mathrm{dT})_{20}(50 \mu \mathrm{M})$ and $1 \mu \mathrm{L}$ dNTP mix $(10 \mathrm{mM})$, and nuclease-free water was added to a total volume of $13 \mu \mathrm{L}$. The mixture was heated at $65^{\circ} \mathrm{C}$ for $5 \mathrm{~min}$ and incubated on ice for $1 \mathrm{~min}$. The volume was increased to $20 \mu \mathrm{L}$ by the addition of $4 \mu \mathrm{L} 5 \times$ first-strand buffer, $1 \mu \mathrm{L}$ RNaseOUT (40 U), and $1 \mu \mathrm{L}$ Superscript III reverse transcriptase (200 U). After incubation at $50{ }^{\circ} \mathrm{C}$ for $60 \mathrm{~min}, 1 \mu \mathrm{L}$ RNase $\mathrm{H}(2 \mathrm{U})$ was added, and incubation was continued at $37^{\circ} \mathrm{C}$ for $20 \mathrm{~min}$.

\subsection{Design of Primers and TaqMan Probes}

Sequences of the complete genomes of LSV (accession numbers: HM222522, AJ516059, AM263208, AM422452, and GU440579), LMoV (accession numbers: AB570195, GU440578, AM048875, GU440579, NC_005288, MT795719, and HM222521), CMV (accession numbers: AB506797, AB506800, AJ495841, and AB049568), SYSV (accession numbers: MK127536 and AJ865076), and PlAMV (accession numbers: AB360790, AB360791, AB360792, LC592411, KU159093, LN794199, KT717325, KU159089, and KX245539) were retrieved from the GenBank database, and conserved regions of each virus were identified using ClustalW (Available online: http:/ / clustalw.ddbj.nig.ac.jp/ (accessed on 16 January 2021)). Virusspecific primers and probes were designed according to the identified conserved regions using Beacon Designer 8.0 (Premier Biosoft, Palo Alto, CA, USA) (Table 1). 
Table 1. Primers and probes used in this study.

\begin{tabular}{|c|c|c|c|c|}
\hline Virus & Primer/Probe & Target Gene & Sequence $\left(5^{\prime}-3^{\prime}\right)$ & $\begin{array}{c}\text { Product } \\
\text { Length }(b p)\end{array}$ \\
\hline \multirow{3}{*}{ LSV } & LSV-F & \multirow{3}{*}{$\mathrm{CP}$} & GCGTCGTATCTAACAACA & \multirow{3}{*}{184} \\
\hline & LSV-R & & GСТССАТТСТСАААСТСА & \\
\hline & LSV-Probe & & CY5-CAAGGAACGCCGAACTGCTC-BHQ3 & \\
\hline \multirow{3}{*}{$\mathrm{LMoV}$} & LMoV-F & \multirow{3}{*}{$\mathrm{CP}$} & CAGTGAAAGACGAGTATG & \multirow{3}{*}{88} \\
\hline & LMoV-R & & GAGGTGCCATTCTCTATG & \\
\hline & LMoV-Probe & & FAM-CAGACCATTCATTGCGAGAGCC-BHQ1 & \\
\hline \multirow{3}{*}{ CMV } & CMV-F & \multirow{3}{*}{$\mathrm{CP}$} & GACAGTCCGTAAAGTTCC & \multirow{3}{*}{105} \\
\hline & CMV-R & & GATGCAGCGTACTGATAA & \\
\hline & CMV-Probe & & Texas Red-TATCCGTTGCCGCCATCTCT-BHQ2 & \\
\hline \multirow{3}{*}{ SYSV } & SYSV-F & \multirow{3}{*}{$\mathrm{CP}$} & GCTTGGATGGTAACATAAG & \multirow{3}{*}{80} \\
\hline & SYSV-R & & CGTGTGATGATCCTTATTC & \\
\hline & SYSV-Probe & & CY5.5-AGAACGACATACAGCAGCCGABHQ2 & \\
\hline \multirow{3}{*}{ PlAMV } & PlAMV-F & \multirow{3}{*}{$\mathrm{CP}$} & CCAACATCAAGTTCGAAC & \multirow{3}{*}{153} \\
\hline & PlAMV-R & & CGAAGAGGTTTAGGGATC & \\
\hline & PlAMV-Probe & & HEX-CGTCTCATTGGCAGTTACTTCGTC-BHQ1 & \\
\hline
\end{tabular}

\subsection{Optimization of the Multiplex TaqMan Real-Time PCR Assay}

The primers and probes used in these assays were listed in Table 1. All reactions were performed on a Bio-Rad CFX96 ${ }^{\mathrm{TM}}$ Real-time System (Bio-Rad, Hercules, CA, USA) For uniplex real-time PCR amplifying LSV, LMoV, CMV, SYSV, and PIAMV, the reaction mixture contained $0.4 \mu \mathrm{L}$ forward primer $(20 \mu \mathrm{M}), 0.4 \mu \mathrm{L}$ reverse primer $(20 \mu \mathrm{M}), 0.4 \mu \mathrm{L}$ TaqMan probe $(20 \mu \mathrm{M}), 10 \mu \mathrm{L} 2 \times$ PerfectStart $^{\circledR}$ II Probe qPCR SuperMix (TransGene, Beijing, China), $2 \mu \mathrm{L}$ template, and nuclease-free water for a total volume of $20.0 \mu \mathrm{L}$. The thermal cycling procedure was initiated at $94{ }^{\circ} \mathrm{C}$ for $30 \mathrm{~s}$, followed by 40 cycles at $94{ }^{\circ} \mathrm{C}$ for $5 \mathrm{~s}$ and $56^{\circ} \mathrm{C}$ for $30 \mathrm{~s}$.

Based on the established uniplex real-time PCR, the multiplex real-time PCR was optimized by varying a single parameter while other parameters were maintained. The multiplex real-time PCR was optimized by varying the annealing temperature and the concentration of primers and probes. Different annealing temperatures were set from 52.0 to $62.0^{\circ} \mathrm{C}\left(52.0^{\circ} \mathrm{C}, 52.7^{\circ} \mathrm{C}, 54.0^{\circ} \mathrm{C}, 55.9^{\circ} \mathrm{C}, 58.4{ }^{\circ} \mathrm{C}, 60.3^{\circ} \mathrm{C}, 61.4^{\circ} \mathrm{C}\right.$, and $\left.62.0^{\circ} \mathrm{C}\right)$, and the concentrations of primers and probes ranged from 10 to $30 \mu \mathrm{M}(10 \mu \mathrm{M}, 15 \mu \mathrm{M}, 20 \mu \mathrm{M}, 25 \mu \mathrm{M}$, and $30 \mu \mathrm{M})$. The optimal PCR conditions were selected based on amplification efficiency determined by the $\mathrm{Cq}$ (Cycle of quantification) value and the fluorescence intensity. All reactions were conducted in triplicates.

\subsection{Construction of Standard Plasmids and Standard Curves}

Conventional RT-PCR assays were used to produced the standard fragments of the target viruses using the primers listed in Table 1 (LSV-F/LSV-R for LSV, LMoV-F/LMoV-R for LMoV, CMV-F/CMV-R for CMV, SYSV-F/SYSV-R for SYSV, and PIAMV-F/PIAMV$\mathrm{R}$ for PlAMV). PCR amplification reactions were performed in a final volume of $50 \mu \mathrm{L}$ containing $1.5 \mu \mathrm{L}$ each primer $(10 \mu \mathrm{M}), 2 \mu \mathrm{L}$ cDNA, $25 \mu \mathrm{L} 2 \times$ KAPA HiFi HotStart Ready Mix (KAPA Biosystems, Wilmington, WA, USA), and $20 \mu \mathrm{L}$ double-distilled water. The thermal cycling conditions were as follows: $95^{\circ} \mathrm{C}$ for $3 \mathrm{~min}$, followed by 35 cycles of $98^{\circ} \mathrm{C}$ for $20 \mathrm{~s}, 56{ }^{\circ} \mathrm{C}$ for $15 \mathrm{~s}, 72{ }^{\circ} \mathrm{C}$ for $30 \mathrm{~s}$, and a final extension at $72{ }^{\circ} \mathrm{C}$ for $2 \mathrm{~min}$. The PCR products were electrophoresed in a $2 \%$ agarose gel in $0.5 \times$ TBE buffer. PCR products were cloned into the $\mathrm{PTOPO}$ vector (Transgen, Beijing, China) to construct recombinant 
plasmids and sequenced with vector primers at Sangon Biotech (Shanghai, China). The concentrations of the recombinant plasmids were quantified using a Nano Drop (Thermo Scientific, Waltham, MA, USA), and the copy number was calculated as follows: number of copies = [amount $\left.(\mathrm{ng}) \times 6.022 \times 10^{23}\right] /[$ length (plasmid + insert $\left.) \times 1 \times 10^{9} \times 650\right]$ [41] Standard curves were obtained using serial ten-fold dilutions of the recombinant plasmids of corresponding viruses.

\subsection{Specificity of the Multiplex Real-Time PCR}

In order to evaluate the specificity of this multiplex real-time PCR assay developed in this study, cDNAs of two other lily viruses, including Strawberry latent ring spot virus (SLRSV; genus Stralarivirus, family Secoviridae) and Arabis mosaic virus (ArMV; genus Nepovirus, family Secoviridae), were used as templates for amplification with this multiplex system. The CDNAs of LSV, LMoV, CMV, SYSV, and PIAMV served as positive controls, and the nuclease-free water was used as a negative template control.

\subsection{Analytical Sensitivity}

To evaluate the detection limits of the multiplex real-time PCR compared with the uniplex real-time PCRs, 10 -fold serial dilutions of the mixture of five recombinant plasmids, ranging from $1.33 \times 10^{9}$ to $1.33 \times 10^{0}$ copies $\mu \mathrm{L}^{-1}, 1.27 \times 10^{9}$ to $1.27 \times 10^{0}$ copies $\mu \mathrm{L}^{-1}$, $1.28 \times 10^{9}$ to $1.28 \times 10^{0}$ copies $\mu \mathrm{L}^{-1}, 2.33 \times 10^{9}$ to $2.33 \times 10^{0}$ copies. $\mu \mathrm{L}^{-1}$, and $2.01 \times 10^{9}$ to $2.01 \times 10^{0}$ copies $\mu \mathrm{L}^{-1}$ for LSV, LMoV, CMV, SYSV, and PlAMV, respectively, were used as templates. Samples with a $\mathrm{Cq}$ value greater than 35 were considered negatives.

\subsection{Reproducibility}

To evaluate the reproducibility of the multiplex real-time PCR, three different concentrations of $10^{7}, 10^{5}$, and $10^{3}$ copies $\mu \mathrm{L}^{-1}$ of standard plasmids were chosen to perform in triplicate on different days. The final coefficient of variation $(\mathrm{CV})$ was calculated to assess intra- and inter-assay variation.

\subsection{Survey of Lily Viruses by the Multiplex Real-Time PCR Assay}

To further evaluate the efficiency of the multiplex real-time PCR assay, 92 lily samples that showed symptoms of leaf mottle, leaf mosaic, leaf curling, chlorotic and yellow streaking, or flower color breaking were collected from lily production fields in China for the detection of LSV, LMoV, CMV, SYSV, and PIAMV using the developed multiplex TaqMan real-time PCR assay. RNA extraction and reverse transcription were performed using the method described in Section 2.2. Multiplex real-time PCR amplification reactions were performed in a final volume of $20 \mu \mathrm{L}$ containing $0.4 \mu \mathrm{L}$ of each of $20 \mu \mathrm{M} \mathrm{LSV}, \mathrm{LMoV}$, CMV, SYSV, and PlAMV primers and probes, $10 \mu \mathrm{L} 2 \times$ PerfectStart $^{\circledR}$ II Probe qPCR SuperMix (TransGene, Beijing, China), $2 \mu \mathrm{L}$ template, and nuclease-free water was added to a total volume of $20.0 \mu \mathrm{L}$. The PCR conditions were determined as follows: $94{ }^{\circ} \mathrm{C}$ for $30 \mathrm{~s}$, followed by 40 cycles at $94{ }^{\circ} \mathrm{C}$ for $5 \mathrm{~s}, 55.9^{\circ} \mathrm{C}$ for $30 \mathrm{~s}$. At the same time, the uniplex real-time PCR was performed using the same samples, and the results of the two methods were compared.

\subsection{Statistical Analysis}

Data analysis and graphing were performed using GraphPad Prism (version 8 for Windows, GraphPad Software, San Diego, CA, USA) and using Jvenn (Available online: http:/ /jvenn.toulouse.inra.fr/app/example.html (accessed on 27 September 2021)) [42].

\section{Results}

\subsection{Optimization of the Multiplex TaqMan Real-Time PCR Assay}

Figure 1 shows the optimum concentrations of primers and probes for the multiplex TaqMan real-time PCR assay, which are 20, 30, 20, 20, and $20 \mu \mathrm{M}$ for LSV, LMoV, CMV, SYSV, and PIAMV, respectively. The results showed the optimum annealing temperatures 
for LSV, LMoV, CMV, SYSV, and PlAMV amplification were 58.4, 55.9, 58.4, 55.9, and $55.9^{\circ} \mathrm{C}$, respectively (Figure 2). Based on the comparison of reaction performance, $20 \mu \mathrm{M}$ and $55.9^{\circ} \mathrm{C}$ were selected to be the optimal primers and probes concentration and reaction annealing temperature.
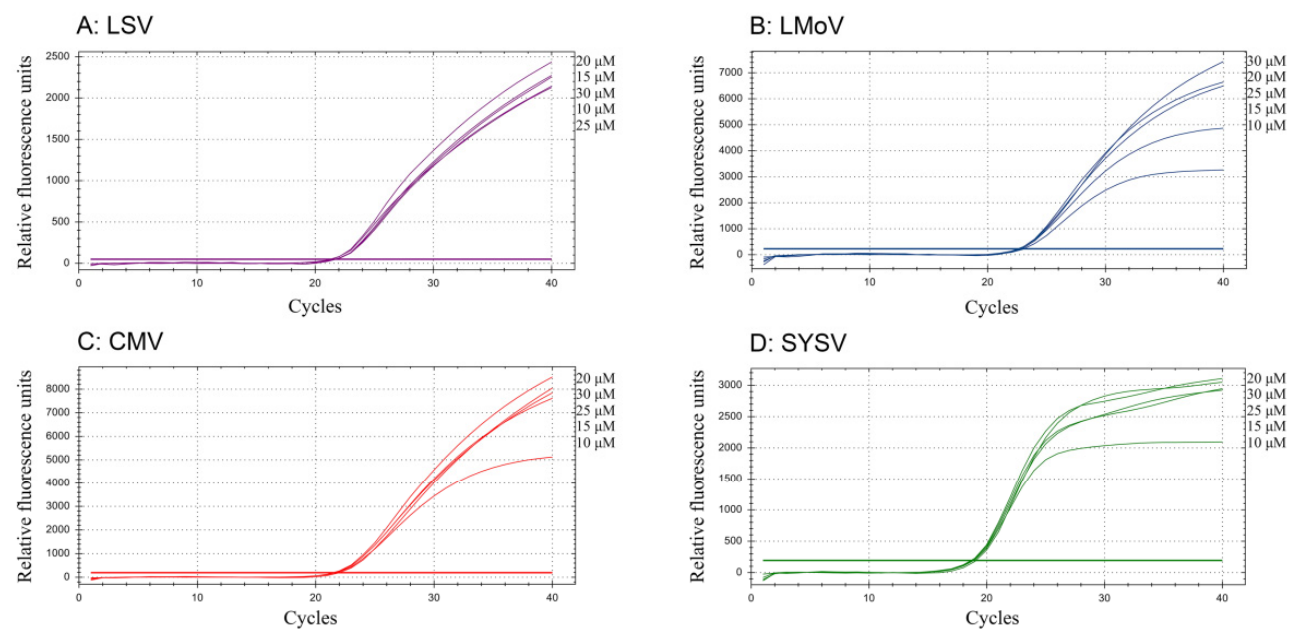

E: PIAMV

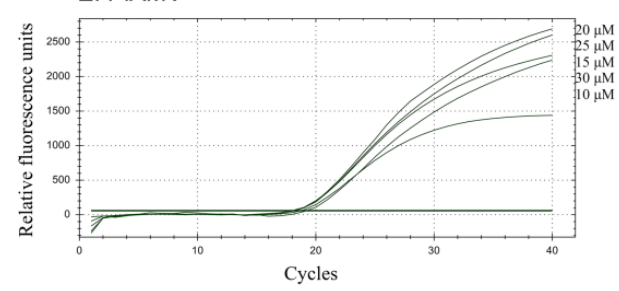

Figure 1. Optimization of the concentration of primers and probes for multiplex TaqMan real-time PCR assay to detect LSV (A), LMoV (B), CMV (C), SYSV (D), and PlAMV (E).
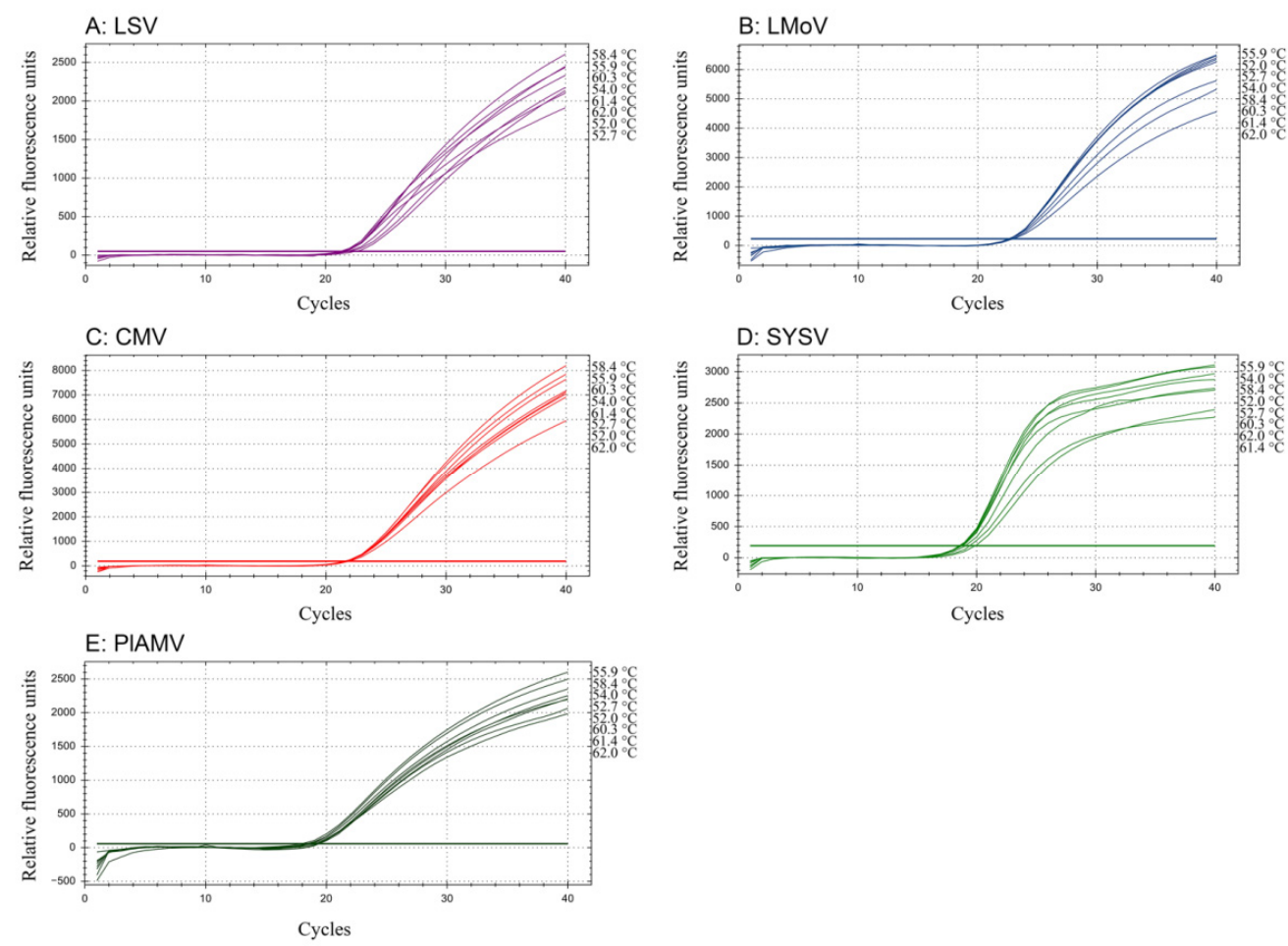

Figure 2. Optimization of the annealing temperature for multiplex TaqMan real-time PCR assay to detect LSV (A), LMoV (B), CMV (C), SYSV (D), and PlAMV (E). 


\subsection{Standard Curves of the Multiplex TaqMan Real-Time PCR Assay}

Fragments of the expected size for LSV, LMoV, CMV, SYSV, and PIAMV were amplified specifically using virus-specific primer pairs (Figure 3) and were cloned into pTOPO vector (Transgen, Beijing, China) to obtain recombinant plasmids pTOPO-LSV, pTOPOLMoV, pTOPO-CMV, pTOPO-SYSV, and pTOPO-PlAMV. The stock of these plasmids had concentrations of $1.33 \times 10^{10}(\mathrm{pTOPO}-\mathrm{LSV}), 1.27 \times 10^{10}(\mathrm{pTOPO}-\mathrm{LMoV}), 1.28 \times 10^{10}$ (pTOPO-CMV), $2.33 \times 10^{10}$ (pTOPO-SYSV), and $2.01 \times 10^{10}$ copies $\cdot \mu \mathrm{L}^{-1}$ (pTOPO-PlAMV). Standard curves were constructed using 10-fold serial dilutions of the recombinant plasmids. The results showed that the correlation coefficients $\left(\mathrm{R}^{2}\right)$ of the five standard curves were above 0.98 (Figure 4), indicating that there was a strong linear relationship between the $\log _{10}$ of the input number of copies and the Cq value of each standard.

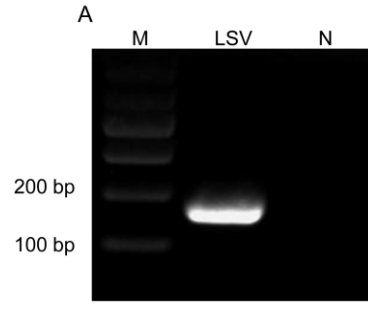

$\mathrm{D}$

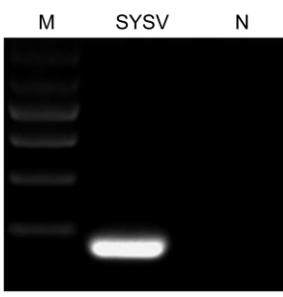

B

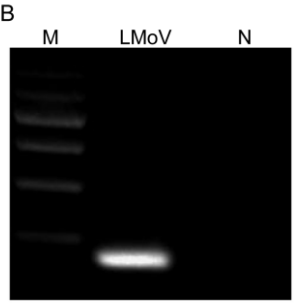

$\mathrm{E}$

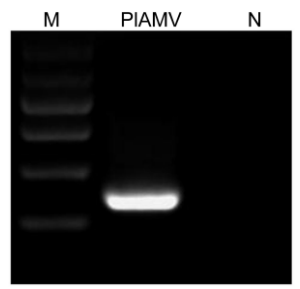

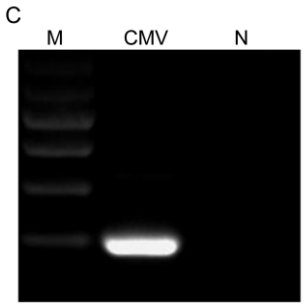
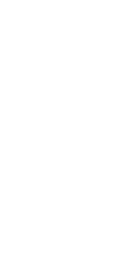

Figure 3. Determination of specificity of five primer pairs by uniplex RT-PCR to detect LSV (A), LMoV (B), CMV (C), SYSV (D), and PIAMV (E). Lane M, 100 bp plus DNA ladde.
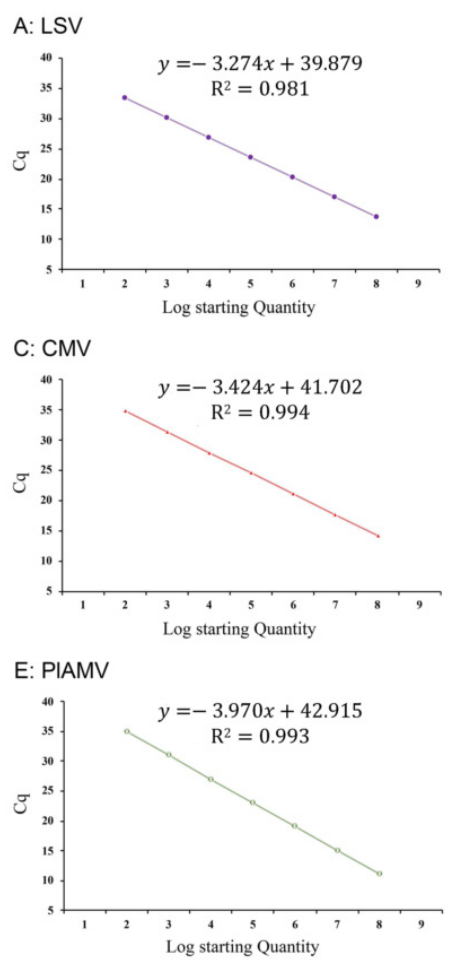
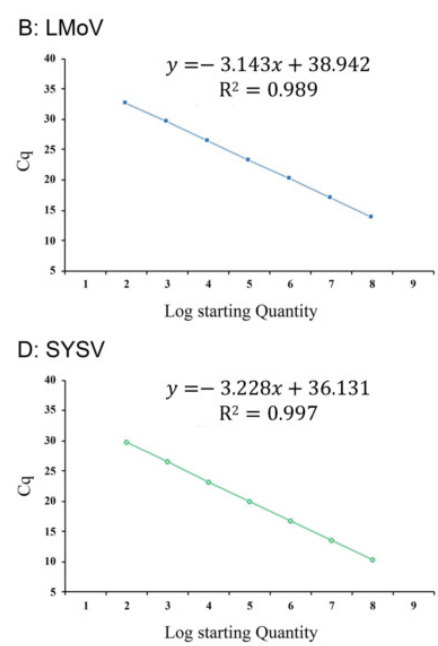

Figure 4. Standard curves obtained by multiplex TaqMan real-time PCR assay for LSV (A), LMoV (B), CMV (C), SYSV (D), and PlAMV (E). 


\subsection{Specificity of the Multiplex TaqMan Real-Time PCR Assay}

The results showed that only the positive samples of LSV, LMoV, CMV, SYSV, and PlAMV showed the amplification curve (Figure $5 \mathrm{~A}-\mathrm{E}, \mathrm{H}$ ), while neither nuclease-free water nor the two non-targeted viruses showed the amplification curve (Figure 5F,G,I).
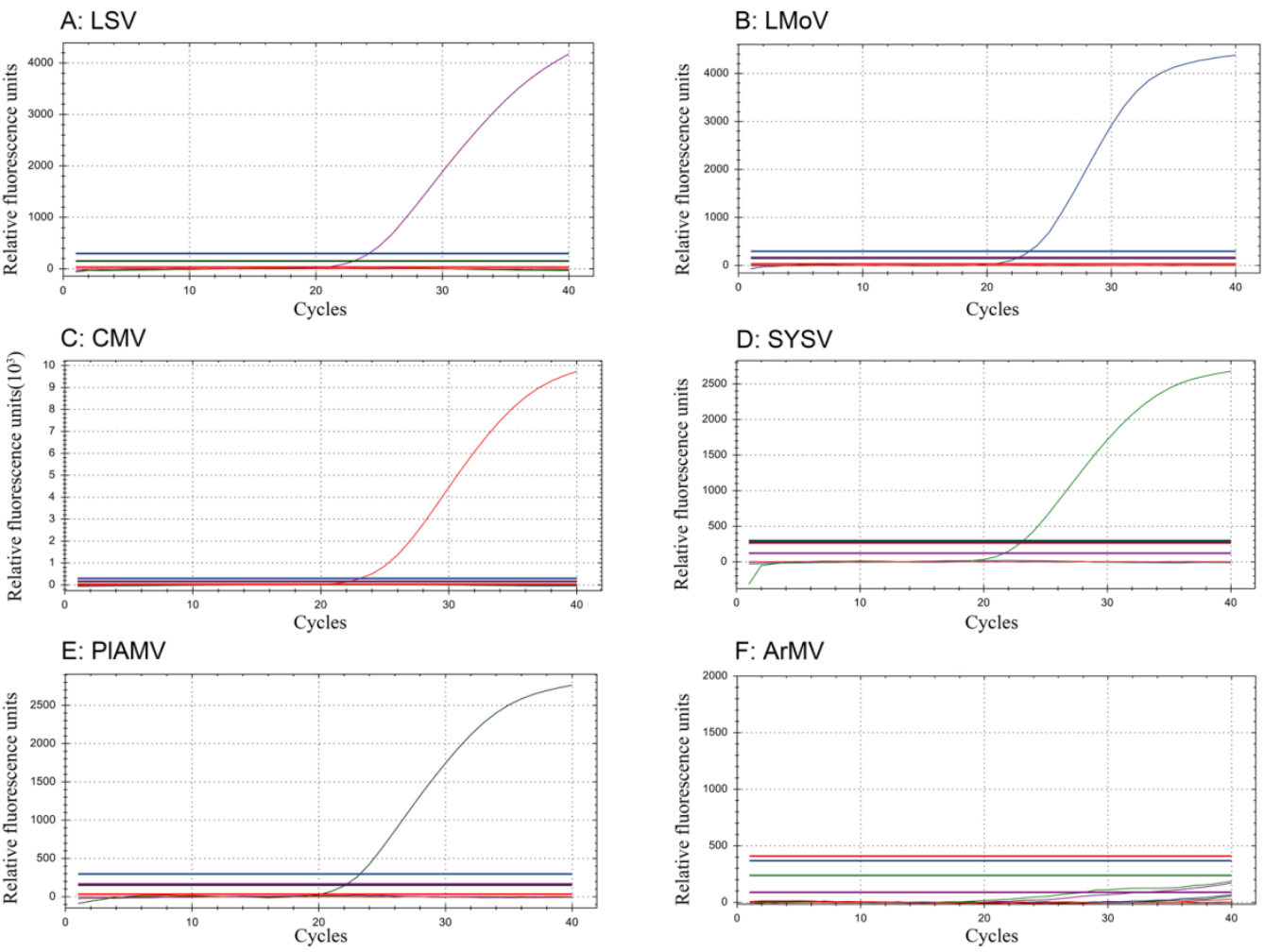

G: SLRSV
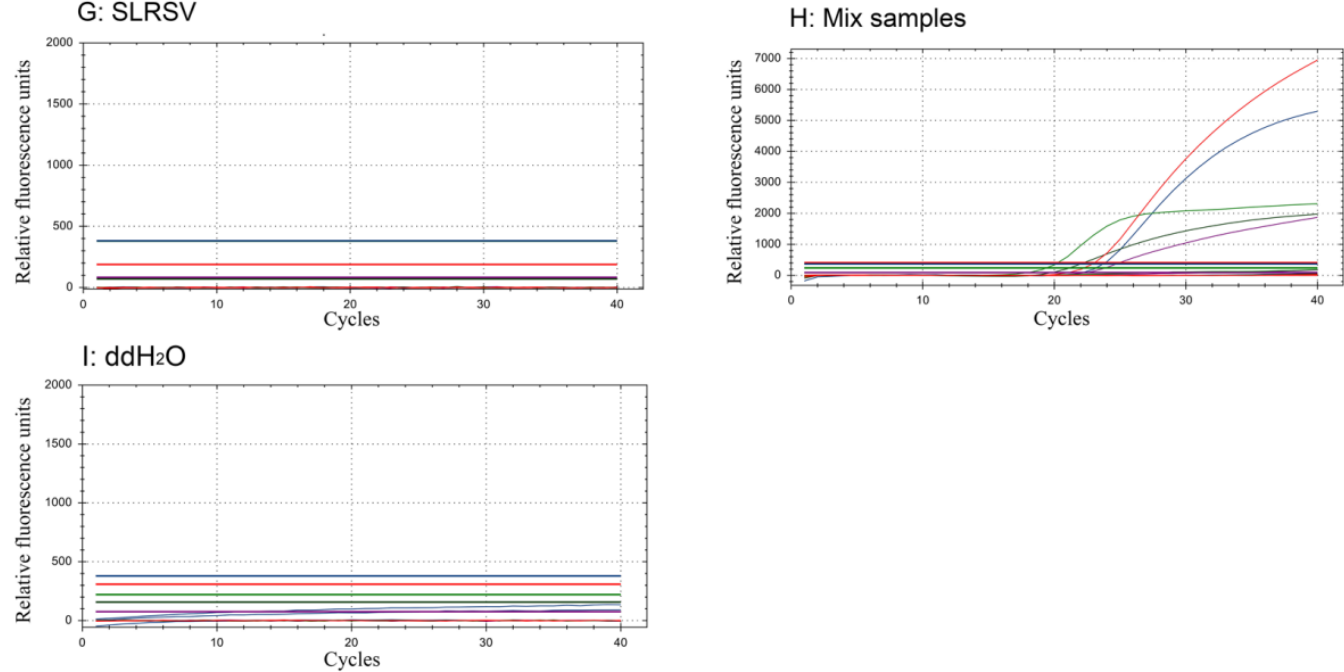

Figure 5. Specificity of multiplex TaqMan real-time PCR. The specific fluorescent signals were detected in the positive samples of LSV (A), LMoV (B), CMV (C), SYSV (D), and PIAMV (E) and mixed samples (H). No cross-reactions were detected from ArMV (F) and SLRSV (G) and $\mathrm{ddH}_{2} \mathrm{O}(\mathbf{I})$.

\subsection{Sensitivity of the Multiplex TaqMan Real-Time PCR Assay}

Sensitivity testing showed that detection limits were $1.33 \times 10^{2}$ for LSV, $1.27 \times 10^{1}$ for LMoV, $1.28 \times 10^{1}$ for CMV, $2.33 \times 10^{2}$ for SYSV, and $2.01 \times 10^{2}$ for PlAMV in both multiplex TaqMan real-time PCR and uniplex TaqMan real-time PCR (Figures 6 and 7). These results indicated that the sensitivity of the multiplex TaqMan real-time PCR was the 
same as that of each uniplex TaqMan real-time PCR assay and that the multiplex TaqMan real-time PCR was suitable for the simultaneous detection of the five viruses.
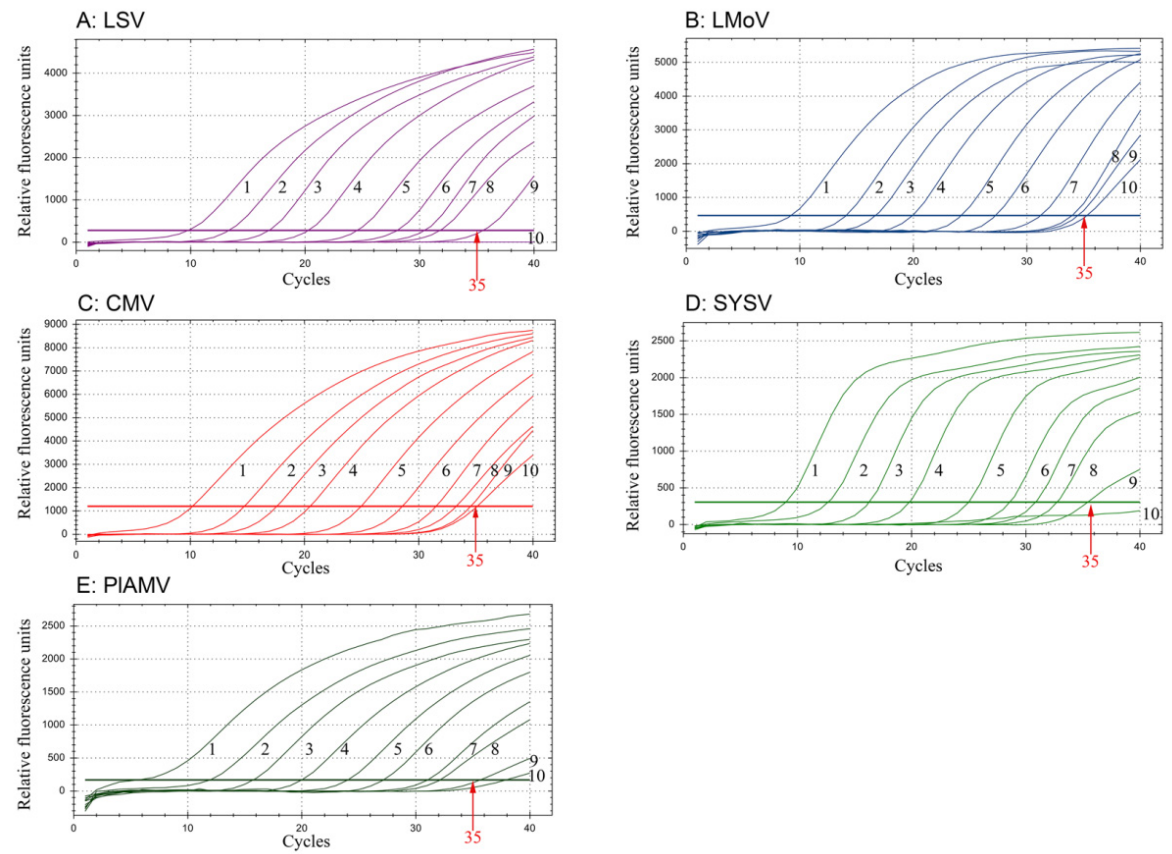

Figure 6. Sensitivity of the multiplex TaqMan real-time PCR assay for LSV (A), LMoV (B), CMV (C), SYSV (D), and PIAMV (E). 1-10, ten-fold serial dilutions of plasmid standard, with the concentrations from $1.33 \times 10^{9}$ to $1.33 \times 10^{0}$ copies $\mu \mathrm{L}^{-1}, 1.27 \times 10^{9}$ to $1.27 \times 10^{0}$ copies $\cdot \mu \mathrm{L}^{-1}, 1.28 \times 10^{9}$ to $1.28 \times 10^{0}$ copies $\cdot \mu \mathrm{L}^{-1}, 2.33 \times 10^{9}$ to $2.33 \times 10^{0}$ copies $\cdot \mu \mathrm{L}^{-1}$, and $2.01 \times 10^{9}$ to $2.01 \times 10^{0}$ copies $\mu \mathrm{L}^{-1}$ for LSV, LMoV, CMV, SYSV, and PIAMV, respectively.
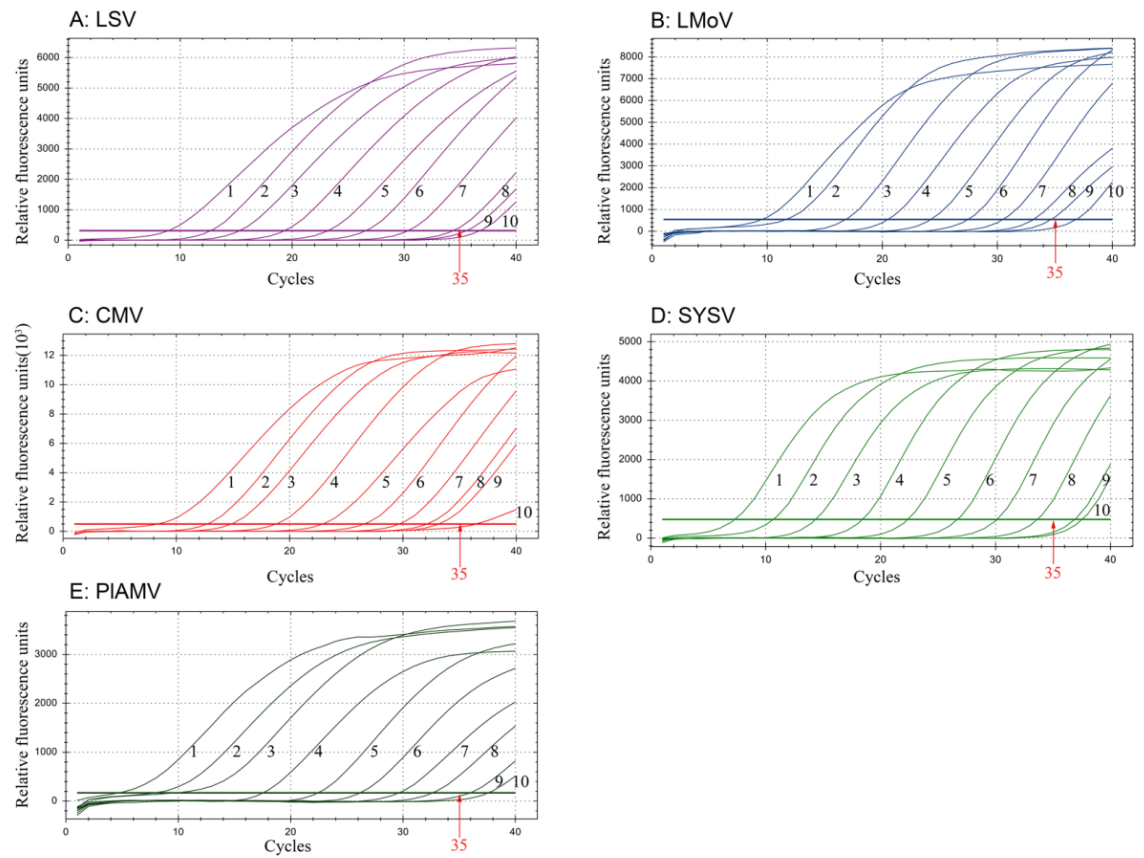

Figure 7. Sensitivity of the uniplex TaqMan real-time PCR assay for LSV (A), LMoV (B), CMV (C), SYSV (D), and PlAMV (E). 1-10, ten-fold serial dilutions of plasmid standard, with the concentrations from $1.33 \times 10^{9}$ to $1.33 \times 10^{0}$ copies $\mu \mathrm{L}^{-1}, 1.27 \times 10^{9}$ to $1.27 \times 10^{0}$ copies $\mu \mathrm{L}^{-1}, 1.28 \times 10^{9}$ to $1.28 \times 10^{0}$ copies $\mu \mathrm{L}^{-1}, 2.33 \times 10^{9}$ to $2.33 \times 10^{0}$ copies $\cdot \mu \mathrm{L}^{-1}$, and $2.01 \times 10^{9}$ to $2.01 \times 10^{0}$ copies $\mu \mathrm{L}^{-1}$ for LSV, LMoV, CMV, SYSV, and PlAMV, respectively. 


\subsection{Repeatability of the Multiplex TaqMan Real-Time PCR Assay}

Different standard plasmids concentrations $\left(10^{7}, 10^{5}\right.$, and $10^{3}$ copies $\left.\mu \mathrm{L}^{-1}\right)$ were chosen to evaluate the intra- and inter-assay repeatability. The $\mathrm{CV}$ values were almost less than $1 \%$, with a few values ranging from $1 \%$ to $2 \%$ (Table 2 ) in the intra- and inter-assays, indicating that the assay has high repeatability and reliability.

Table 2. Intra- and inter-assay reproducibility of multiplex TaqMan real-time PCR.

\begin{tabular}{|c|c|c|c|c|c|c|c|c|}
\hline \multirow{2}{*}{ Plasmid } & \multirow{2}{*}{\multicolumn{2}{|c|}{$\begin{array}{l}\text { Concentration } \\
\left(\text { Copies } \mu \mathrm{L}^{-1}\right)\end{array}$}} & \multicolumn{3}{|c|}{ Intra-Assay Cq Value } & \multicolumn{3}{|c|}{ Inter-Assay Cq Value } \\
\hline & & & Mean & SD & CV\% & Mean & SD & CV\% \\
\hline \multirow{3}{*}{ LSV } & \multirow{3}{*}{$1.33 \times$} & $10^{7}$ & 17.05 & 0.29 & 1.68 & 17.68 & 0.02 & 0.11 \\
\hline & & $10^{5}$ & 25.80 & 0.30 & 1.15 & 26.74 & 0.07 & 0.27 \\
\hline & & $10^{3}$ & 31.17 & 0.07 & 0.23 & 31.53 & 0.18 & 0.58 \\
\hline \multirow{3}{*}{$\mathrm{LMoV}$} & \multirow{3}{*}{$1.27 \times$} & $10^{7}$ & 17.41 & 0.02 & 0.12 & 16.39 & 0.21 & 1.30 \\
\hline & & $10^{5}$ & 23.84 & 0.12 & 0.49 & 23.97 & 0.22 & 0.93 \\
\hline & & $10^{3}$ & 30.65 & 0.16 & 0.52 & 31.15 & 0.13 & 0.42 \\
\hline \multirow{3}{*}{$\mathrm{CMV}$} & \multirow{3}{*}{$1.28 \times$} & $10^{7}$ & 18.40 & 0.21 & 1.14 & 18.56 & 0.08 & 0.41 \\
\hline & & $10^{5}$ & 26.20 & 0.20 & 0.76 & 26.23 & 0.20 & 0.76 \\
\hline & & $10^{3}$ & 30.89 & 0.14 & 0.44 & 30.64 & 0.19 & 0.61 \\
\hline \multirow{3}{*}{ SYSV } & \multirow{3}{*}{$2.33 \times$} & $10^{7}$ & 16.02 & 0.15 & 0.94 & 16.08 & 0.09 & 0.54 \\
\hline & & $10^{5}$ & 24.30 & 0.05 & 0.19 & 24.48 & 0.07 & 0.27 \\
\hline & & $10^{3}$ & 30.59 & 0.04 & 0.14 & 31.21 & 0.08 & 0.27 \\
\hline \multirow{3}{*}{ PlAMV } & \multirow{3}{*}{$2.01 \times$} & $10^{7}$ & 15.80 & 0.28 & 1.77 & 15.51 & 0.12 & 0.77 \\
\hline & & $10^{5}$ & 24.29 & 0.46 & 1.89 & 23.61 & 0.24 & 1.03 \\
\hline & & $10^{3}$ & 31.65 & 0.55 & 1.74 & 32.09 & 0.08 & 0.25 \\
\hline
\end{tabular}

\subsection{Application of Multiplex TaqMan Real-Time PCR Assay in Survey of Lily Viruses}

The results of the multiplex TaqMan real-time PCR assay showed that all samples were infected with at least three viruses (Table S1). LSV, LMoV, CMV, SYSV, and PlAMV were detected in $92(100.00 \%), 61(66.30 \%), 92(100.00 \%), 76(82.61 \%)$, and $72(78.26 \%)$ of the 92 samples, respectively (Figure 8A). There were 8 samples co-infected with three viruses, 51 samples co-infected with four viruses, and 33 samples co-infected with five viruses (Figure 8B). All collected samples were further tested using the uniplex TaqMan real-time PCR, and the results were consistent with those of the multiplex TaqMan real-time PCR assay (data not shown). Thus, the multiplex TaqMan real-time PCR assay developed in this study was confirmed to be a rapid and accurate detection method. 

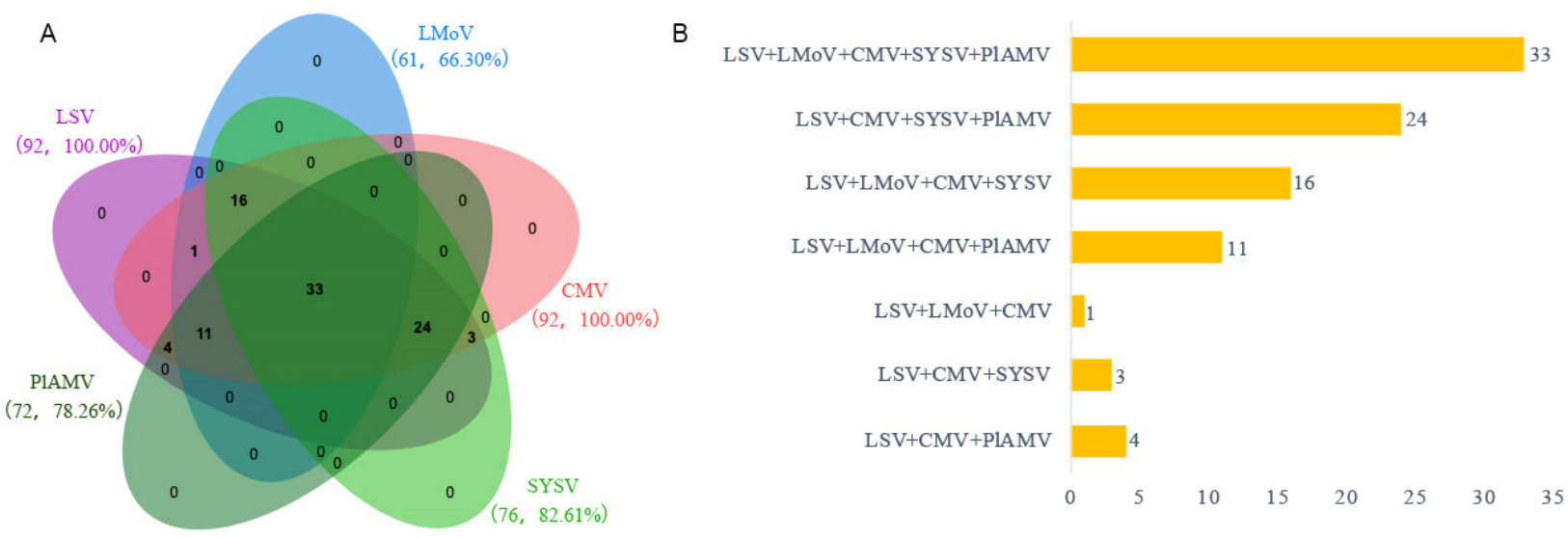

Figure 8. Detection of five viruses in lily plants in China using multiplex TaqMan real-time PCR assay. (A) Venn diagram illustrating the number of samples infected by multiplex TaqMan real-time PCR assay. (B) Number of samples infected with different viruses.

\section{Discussion}

Primer design is the most important step in establishing an efficient multiplex TaqMan real-time PCR assay. Ideally, primers should be specific, have low or no interference in the amplification reaction [38]. In this study, considering the wide genetic diversity of LSV, LMoV, CMV, SYSV, and PIAMV, virus-specific primers were designed according to conserved regions in each viral genome. Using the final primers, five expected amplicons (184 bp for LSV, $88 \mathrm{bp}$ for LMoV, $105 \mathrm{bp}$ for CMV, $80 \mathrm{bp}$ for SYSV, and $153 \mathrm{bp}$ for PIAMV) were produced (Figure 3). And, using this multiplex TaqMan real-time PCR, only the positive samples of LSV, LMoV, CMV, SYSV, and PIAMV showed the amplification curve (Figure 5), revealing that this newly developed assay was highly specific.

The optimization of PCR conditions is essential for efficient PCR amplification. In this study, serial PCRs were conducted to determine the optimal concentration of primers and probes and annealing temperature. The results showed the $\mathrm{Cq}$ value and the fluorescence intensity were highest when the concentration of primers and probes and the reaction annealing temperature were $20 \mu \mathrm{M}$ and $55.9^{\circ} \mathrm{C}$, respectively (Figures 1 and 2). Generally, the presence of more than one pair of primers in the same reaction mix may limit the sensitivity or cause preferential amplification of specific targets [43], and the sensitivity of the multiplex PCR is usually about 10-fold lower than that of a uniplex PCR [36]. Fortunately, the sensitivity of the optimized multiplex TaqMan real-time PCR assay was the same as that of each uniplex assay in our previous study, indicating that a desired primer design and the proper optimization of the multiplex TaqMan real-time PCR assay were developed.

Viral diseases frequently occur in lily plants, and they affect bulb and cut-flower production [4-9]. In this study, 92 lily samples in China were tested using the developed multiplex TaqMan real-time PCR assay. The results showed all samples were infected with at least three viruses (Table S1, Figure 8). The high occurrence of viruses infecting lilies in China could be due to the use of virus-infected bulbs for propagation and the lack of preventive virus vector control measures. Hence, it is urgent to use virus-free propagation materials and to take extreme precautions to produce virus-free lily bulbs.

In conclusion, an effective multiplex TaqMan real-time PCR assay was established for the simultaneous detection and differentiation of LSV, LMoV, CMV, SYSV, and PIAMV in lilies. This assay will be useful for routine molecular diagnosis and epidemiological studies of these viruses.

Supplementary Materials: The following supporting information can be downloaded at: https:/ / www.mdpi.com/article/10.3390/agronomy12010047/s1, Table S1: Survey of viral infection in lily plants in China using the multiplex TaqMan real-time PCR assay. 


\begin{abstract}
Author Contributions: Validation, L.X. and M.S.; formal analysis, M.S.; investigation, L.X. and M.S.; resources, L.X.; data curation, L.X. and J.M.; writing-original draft preparation, L.X.; writingreview and editing, J.M.; project administration, J.M.; funding acquisition, L.X. and J.M. All authors have read and agreed to the published version of the manuscript.

Funding: This study was supported by the National Key Research and Development Program of China (2019YFD1001805, 2018YFD1000405, and 2019YFD1001002), the National Natural Science Foundation of China (31801899 and 31672196), and the Science and Technology Innovation Program of the Chinese Academy of Agricultural Sciences. This research was conducted at the Key Laboratory of Biology and Genetic Improvement of Horticultural Crops, Ministry of Agriculture, China.
\end{abstract}

Conflicts of Interest: The authors declare no conflict of interest.

\title{
References
}

1. Munafo, J.P., Jr.; Ramanathan, A.; Jimenez, L.S.; Gianfagna, T.J. Isolation and structural determination of steroidal glycosides from the bulbs of easter lily (Lilium longiflorum Thunb.). J. Agric. Food Chem. 2010, 58, 8806-8813. [CrossRef]

2. Jin, L.; Zhang, Y.; Yan, L.; Guo, Y.; Niu, L. Phenolic compounds and antioxidant activity of bulb extracts of six Lilium species native to China. Molecules 2012, 17, 9361-9378. [CrossRef] [PubMed]

3. Bakhshaie, M.; Khosravi, S.; Azadi, P.; Bagheri, H.; van Tuyl, J.M. Biotechnological advances in Lilium. Plant Cell Rep. 2016, 35, 1799-1826. [CrossRef]

4. Asjes, C.J. Control of aphid-borne Lily symptomless virus and Lily mottle virus in Lilium in the Netherlands. Virus Res. 2000, 71, 23-32. [CrossRef]

5. Komatsu, K.; Yamaji, Y.; Ozeki, J.; Hashimoto, M.; Kagiwada, S.; Takahashi, S.; Namba, S. Nucleotide sequence analysis of seven Japanese isolates of Plantago asiatica mosaic virus (PlAMV): A unique potexvirus with significantly high genomic and biological variability within the species. Arch. Virol. 2008, 153, 193-198. [CrossRef]

6. Chinestra, S.C.; Facchinetti, C.; Curvetto, N.R.; Marinangeli, P.A. Detection and frequency of lily viruses in argentina. Plant Dis. 2010, 94, 1188-1194. [CrossRef]

7. Zhang, Y.; Wang, Y.; Xie, Z.; Yang, G.; Guo, Z.; Wang, L. Simultaneous detection of three lily viruses using Triplex IC-RT-PCR. J. Virol. Methods 2017, 249, 69-75. [CrossRef] [PubMed]

8. Yang, P.; He, G.; Cao, Y.; Xu, L.; Ming, J. First Report of Shallot yellow stripe virus in Lilium lancifolium in China. Plant Dis. 2019, 103, 2146. [CrossRef]

9. Tanaka, M.; Verbeek, M.; Takehara, M.; Pham, K.; Lemmers, M.; Slootweg, C.; Arie, T.; Komatsu, K. Differences in infectivity and pathogenicity of two Plantago asiatica mosaic virus isolates in lilies. Eur. J. Plant Pathol. 2019, 153, 813-823. [CrossRef]

10. Le, T.B.; Kim, H.K.; Na, W.; Le, V.P.; Song, M.-S.; Song, D.; Jeong, D.G.; Yoon, S.-W. Development of a Multiplex RT-qPCR for the Detection of Different Clades of Avian Influenza in Poultry. Viruses 2020, 12, 100. [CrossRef] [PubMed]

11. Webster, C.G.; Turechek, W.W.; Li, W.; Kousik, C.S.; Adkins, S. Development and Evaluation of ELISA and qRT-PCR for Identification of Squash vein yellowing virus in Cucurbits. Plant Dis. 2017, 101, 178-185. [CrossRef] [PubMed]

12. Zhang, L.; Du, X.; Chen, C.; Chen, Z.; Zhang, L.; Han, Q.; Xia, X.; Song, Y.; Zhang, J. Development and characterization of double-antibody sandwich ELISA for detection of Zika virus infection. Viruses 2018, 10, 634. [CrossRef] [PubMed]

13. Zhou, Q.; Bi, Z.; Yin, D.; Gu, X.; Xu, Z.; Huang, R.; Xing, X.; Qi, K.; Wang, G. Development and application of an indirect ELISA for the serological detection of duck Tembusu virus infection based on the NS1 protein antigen. Arch. Virol. 2020, 165, 709-714. [CrossRef]

14. Santiago, G.A.; Vázquez, J.; Courtney, S.; Matías, K.Y.; Andersen, L.E.; Colón, C.; Butler, A.E.; Roulo, R.; Bowzard, J.; Villanueva, J.M.; et al. Performance of the Trioplex real-time RT-PCR assay for detection of Zika, dengue, and chikungunya viruses. Nat. Commun. 2018, 9, 1391. [CrossRef]

15. Diaz-Lara, A.; Stevens, K.; Klaassen, V.; Golino, D.; Al Rwahnih, M. Comprehensive Real-Time RT-PCR Assays for the Detection of Fifteen Viruses Infecting Prunus spp. Plants 2020, 9, 273. [CrossRef]

16. Mahapatra, M.; Howson, E.; Fowler, V.; Batten, C.; Flannery, J.; Selvaraj, M.; Parida, S. Rapid Detection of Peste des Petits Ruminants Virus (PPRV) Nucleic Acid Using a Novel Low-Cost Reverse Transcription Loop-Mediated Isothermal Amplification (RT-LAMP) Assay for Future Use in Nascent PPR Eradication Programme. Viruses 2019, 11, 699. [CrossRef]

17. Liu, I.-L.; Lin, Y.-C.; Lin, Y.-C.; Jian, C.-Z.; Cheng, I.-C.; Chen, H.-W. A Novel Immunochromatographic Strip for Antigen Detection of Avian Infectious Bronchitis Virus. Int. J. Mol. Sci. 2019, 20, 2216. [CrossRef] [PubMed]

18. Niimi, Y.; Han, D.S.; Fujisaki, M. Production of virus-free plantlets by anther culture of Lilium $\times$ 'Enchantment'. Sci. Hortic. 2001, 90, 325-334. [CrossRef]

19. Niimi, Y.; Han, D.S.; Mori, S.; Kobayashi, H. Detection of Cucumber mosaic virus, Lily symptomless virus and Lily mottle virus in Lilium species by RT-PCR technique. Sci. Hortic. 2003, 97, 57-63. [CrossRef]

20. Zhao, B.; Yang, D.; Zhang, Y.; Xu, Y.; Zhao, X.; Liang, J.; Fan, X.; Du, Y.; Zhu, Z.; Shi, B.; et al. Rapid visual detection of Lily mottle virus using a loop-mediated isothermal amplification method. Arch. Virol. 2018, 163, 545-548. [CrossRef] 
21. Zhao, X.; Du, Y.; Zhang, Y.; Liang, J.; Cai, Y.; Xu, Y.; Fan, X.; Wu, W.; Zhang, Q.; Zhang, X.; et al. Effective detection of Lily symptomless virus using the reverse transcription loop-mediated isothermal amplification method. Australas. Plant Pathol. 2019, 48, 373-374. [CrossRef]

22. Zhang, Y.; Wang, Y.; Xie, Z.; Wang, R.; Guo, Z.; He, Y. Rapid Detection of Lily mottle virus and Arabis mosaic virus Infecting Lily (Lilium spp.) Using Reverse Transcription Loop-Mediated Isothermal Amplification. Plant Pathol. J. 2020, 36, 170-178. [CrossRef]

23. Elnifro, E.M.; Ashshi, A.M.; Cooper, R.J.; Klapper, P.E. Multiplex PCR: Optimization and application in diagnostic virology. Clin. Microbiol. Rev. 2000, 13, 559-570. [CrossRef]

24. Giry, C.; Roquebert, B.; Li-Pat-Yuen, G.; Gasque, P.; Jaffar-Bandjee, M.C. Simultaneous detection of Chikungunya virus, dengue virus and human pathogenic Leptospira genomes using a multiplex TaqMan®assay. BMC Microbiol. 2017, 17, 105. [CrossRef] [PubMed]

25. Wolff, B.J.; Morrison, S.S.; Winchell, J.M. Development of a multiplex TaqMan real-time PCR assay for the detection of Chlamydia psittaci and Chlamydia pneumoniae in human clinical specimens. Diagn. Microbiol. Infect. Dis. 2018, 90, 167-170. [CrossRef]

26. Zhen, W.; Berry, G.J. Development of a New Multiplex Real-Time RT-PCR Assay for Severe Acute Respiratory Syndrome Coronavirus 2 (SARS-CoV-2) Detection. J. Mol. Diagn. 2020, 22, 1367-1372. [CrossRef]

27. Yu, Z.; Wu, H.; Huang, Q.; Zhong, Z. Simultaneous detection of Marburg virus and Ebola virus with TaqMan-based multiplex real-time PCR method. J. Clin. Lab. Anal. 2021, 35, 6. [CrossRef] [PubMed]

28. Yuan, W.; Wang, J.; Xu, F.; Huang, B.; Lian, Y.; Rao, D.; Yin, X.; Wu, M.; Zhu, Y.; Zhang, Y.; et al. Development of a duplex real-time RT-PCR for the simultaneous detection and differentiation of Theiler's murine encephalomyelitis virus and rat theilovirus. J. Virol. Methods 2016, 236, 139-146. [CrossRef] [PubMed]

29. Calixto, R.; Oliveira, G.; Lima, M.; Andrade, A.C.; Trindade, G.D.S.; De Oliveira, D.B.; Kroon, E.G. A Model to Detect Autochthonous Group 1 and 2 Brazilian Vaccinia virus Coinfections: Development of a qPCR Tool for Diagnosis and Pathogenesis Studies. Viruses 2018, 10, 15. [CrossRef] [PubMed]

30. Liu, L.; Zhang, Y.; Cui, P.; Wang, C.; Zeng, X.; Deng, G.; Wang, X. Development of a duplex TaqMan real-time RT-PCR assay for simultaneous detection of newly emerged H5N6 influenza viruses. Virol. J. 2019, 16, 1. [CrossRef]

31. Zhang, Z.; Liu, D.; Hu, J.; Sun, W.; Liu, K.; Li, J.; Xu, H.; Liu, J.; He, L.; Jiang, D.; et al. Multiplex one-step real-time PCR assay for rapid simultaneous detection of velogenic and mesogenic Newcastle disease virus and H5-subtype avian influenza virus. Arch. Virol. 2019, 164, 1111-1119. [CrossRef]

32. Wang, R.; Zhang, W.; Ye, R.; Pan, Z.; Li, G.; Su, S. One-step multiplex TaqMan probe-based method for real-time PCR detection of four canine diarrhea viruses. Mol. Cell. Probes 2020, 53, 101618. [CrossRef] [PubMed]

33. Huang, X.; Chen, J.; Yao, G.; Guo, Q.; Wang, J.; Liu, G. A TaqMan-probe-based multiplex real-time RT-qPCR for simultaneous detection of porcine enteric coronaviruses. Appl. Microbiol. Biotechnol. 2019, 103, 4943-4952. [CrossRef] [PubMed]

34. Šimenc, L.; Knific, T.; Toplak, I. The Comparison of Honeybee Viral Loads for Six Honeybee Viruses (ABPV, BQCV, CBPV, DWV, LSV3 and SBV) in Healthy and Clinically Affected Honeybees with TaqMan Quantitative Real-Time RT-PCR Assays. Viruses 2021, 13, 1340. [CrossRef]

35. Caraballo, D.A.; Lombardo, M.A.; Becker, P.; Sabio, M.S.; Lema, C.; Martínez, L.M.; Beltrán, F.J.; Li, Y.; Cisterna, D.M. Evaluation of Two Real-Time, TaqMan Reverse Transcription-PCR Assays for Detection of Rabies Virus in Circulating Variants from Argentina: Influence of Sequence Variation. Viruses 2021, 13, 23. [CrossRef] [PubMed]

36. Malandraki, I.; Varveri, C.; Olmos, A.; Vassilakos, N. One-step multiplex quantitative RT-PCR for the simultaneous detection of viroids and phytoplasmas of pome fruit trees. J. Virol. Methods 2015, 213, 12-17. [CrossRef]

37. Lan, P.; Li, F.; Abad, J.; Pu, L.; Li, R. Simultaneous detection and differentiation of three Potyviridae viruses in sweet potato by a multiplex TaqMan real time RT-PCR assay. J. Virol. Methods 2018, 252, 24-31. [CrossRef]

38. Pappi, P.G.; Fotiou, I.; Efthimiou, K.E.; Katis, N.I.; Maliogka, V.I. Development of three duplex real-time RT-PCR assays for the sensitive and rapid detection of a phytoplasma and five viral pathogens affecting stone fruit trees. Mol. Cell. Probes 2020, 53, 101621. [CrossRef]

39. Alsaheli, Z.; Abdallah, A.; Incerti, O.; Shalaby, A.; Youssef, S.; Digiaro, M.; Elbeaino, T. Development of singleplex and multiplex real-time (Taqman $\left.{ }^{\circledR}\right)$ RT-PCR assays for the detection of viruses associated with fig mosaic disease. J. Virol. Methods 2021, 293, 114145. [CrossRef]

40. Diaz-Lara, A.; Stevens, K.A.; Klaassen, V.; Hwang, M.S.; Al Rwahnih, M. Sequencing a Strawberry Germplasm Collection Reveals New Viral Genetic Diversity and the Basis for New RT-qPCR Assays. Viruses 2021, 13, 1442. [CrossRef]

41. Lamien, C.E.; Lelenta, M.; Goger, W.; Silber, R.; Tuppurainen, E.; Matijevic, M.; Luckins, A.G.; Diallo, A. Real time PCR method for simultaneous detection, quantitation and differentiation of capripoxviruses. J. Virol. Methods 2011, 171, 134-140. [CrossRef] [PubMed]

42. Bardou, P.; Mariette, J.; Escudie, F.; Djemiel, C.; Klopp, C. jvenn: An interactive Venn diagram viewer. BMC Bioinform. 2014, 15, 293. [CrossRef] [PubMed]

43. Markoulatos, P.; Siafakas, N.; Moncany, M. Multiplex polymerase chain reaction: A practical approach. J. Clin. Lab. Anal. 2002, 16, 47-51. [CrossRef] [PubMed] 